Syntax Literate: Jurnal Ilmiah Indonesia p-ISSN: 2541-0849

e-ISSN: 2548-1398

Vol. 6, No. 10, Oktober 2021

\title{
PENGARUH STRUKTUR MODAL TERHADAP KINERJA PERUSAHAAN PERUSAHAAN MAKANAN DAN MINUMAN DI INDONESIA
}

\author{
Pandu Adi Cakranegara, Debby Danila Wati \\ Universitas Presiden Bekasi Jawa Barat, Indonesia \\ Email: pandu.cakranegara@president.ac.id, debbywu100601@gmail.com
}

\begin{abstract}
Abstrak
Struktur modal berpengaruh terhadap nilai perusahaan. Namun struktur modal yang maksimum bagi perusahaan berbeda-beda. Perusahaan makanan dan minuman secara operasional memiliki jumlah aset lancar yang tinggi sehingga kebutuhan akan utang jangka pendeknya menjadi besar. Studi ini bertujuan untuk memeriksa dampak struktur modal perusahaan makanan dan minuman terhadap kinerja yang diwakili oleh indikator profitabilitas. Studi ini menggunakan metode kuantitatif dan analisis regresi berganda untuk menganalisis variabel. Model efek acak dipilih sebagai model dan menggunakan EViews 10 sebagai alat penelitian. Data penelitian ini diambil dari laporan keuangan, yang diterbitkan setiap tahun. Sampel penelitian adalah sembilan perusahaan makanan dan minuman terpilih yang memenuhi kriteria dan terdaftar di bursa efek Indonesia selama 2013-2019. Hasil penelitian mengungkapkan bahwa utang jangka pendek dan utang jangka panjang memiliki dampak negatif yang signifikan terhadap profitabilitas. Bersamaan dengan itu, arus kas dari kegiatan operasi, pertumbuhan penjualan, dan ukuran perusahaan secara positif dan signifikan. Penentuan koefisien menunjukkan bahwa variabel independen secara bersamaan dapat menjelaskan 52,67\% dari laba atas aset. Manajer perusahaan dan investor dapat menggunakan hasil penelitian ini untuk mengevaluasi kinerja perusahaan.
\end{abstract}

Kata Kunci: struktur modal; arus kas dari operasi; ukuran perusahaan; laba atas aset

\section{Abstract}

Capital structure has an effect on firm value. However, the maximum capital structure for companies is different. Food and beverage companies operationally have a high number of current assets so that the need for short-term debt is large. This study aims to examine the impact of the capital structure of food and beverage companies on performance as represented by profitability indicators. This study uses quantitative methods and multiple regression analysis to analyze the variables. A random effects model was selected as the model and used EViews 10 as a research tool. The data of this research are taken from financial reports, which are published every year. The research sample is nine selected food and beverage companies that meet the criteria and are listed on the Indonesian stock exchange during 2013-2019. The results reveal that short-term debt and long-term debt have a significant negative impact on profitability. At the same time, cash flow from operating activities, sales growth, and company size are positive and significant.

$\begin{array}{ll}\text { How to cite: } & \text { Cakranegara. P. A \& Wati, D. D. (2021) Pengaruh Struktur Modal Terhadap Kinerja Perusahaan Perusahaan } \\ & \text { Makanan dan Minuman Di Indonesia. Syntax Literate: Jurnal Ilmiah Indonesia, 6(10). } \\ & \text { http://dx.doi.org/10.36418/ Syntax-Literate.v6i10.4274 } \\ \text { E-ISSN: } & 2548-1398 \\ \text { Published by: } & \text { Ridwan Institute }\end{array}$


The determination of the coefficients shows that the independent variables can simultaneously explain $52.67 \%$ of the return on assets. Company managers and investors can use the results of this study to evaluate the company's performance.

Keywords: capital structures; cash flow from operations; firm size; return on assets

Received: 2021-09-20; Accepted: 2021-10-05; Published: 2021-10-20

\section{Pendahuluan}

Sektor makanan dan minuman telah menjadi salah satu industri yang paling berkembang di dunia. Pada tahun 2019, jumlah penduduk Indonesia menempati urutan keempat secara global, dengan jumlah total 271 Juta jiwa, sumber dari Bank Dunia tahun 2019. Sebagai manusia, kita perlu mengonsumsi makanan dan air untuk mendapatkan energi dan nutrisi untuk bertahan hidup. Otomatis hal ini menjadi salah satu alasan mengapa industri makanan dan minuman tetap eksis.

Pola dan tren konsumsi pangan masyarakat di dunia terus berkembang pesat sejak seratus tahun terakhir, di mana Indonesia menjadi salah satunya. Pertumbuhan industri makanan dan minuman juga dipengaruhi oleh pendapatan, pengetahuan, dan kesadaran masyarakat yang lebih baik akan kesehatannya, sehingga konsumen menyadari kebutuhannya akan makanan yang lebih sehat dan lebih beragam (Peterson, 2017). Permintaan makanan dan minuman akan terus meningkat seiring dengan pertambahan jumlah penduduk Indonesia. Di Negara Indonesia, industri pengolahan makanan dan minuman menjadi salah satu industri penunjang pertumbuhan ekonomi nasional.

Menurut (Saputra \& Sukirno, 2020), manufaktur adalah kegiatan ekonomi yang mengolah komoditas esensial menjadi komoditas akhir atau antara melalui metode mekanis, kimiawi, atau manual. Ini juga dapat dijelaskan sebagai proses mengubah komoditas bernilai rendah menjadi produk akhir atau setengah jadi.

Persentase PMDN meningkat dari 2015-2019, sedangkan kondisi PMA sebaliknya. Pada 2019, penanaman modal asing menyentuh 52,3\%, lebih rendah $2,1 \%$ dibandingkan tahun 2018. Di saat yang sama, proporsi penanaman modal dalam negeri meningkat dari 45,6\% menjadi 47,7\%. Pada Gambar 1.2, kita dapat melihat investasi masing-masing sektor oleh investor domestik dari tahun 2015 hingga triwulan pertama tahun 2020.

Globalisasi memaksa perusahaan domestik untuk bersaing dengan produk dari luar negeri. Untuk dapat bertahan, perusahaan harus melalui setiap tantangan yang dihadapi, baik dari masalah internal maupun eksternal (Purwanto, 2011). Untuk bertahan hidup, perusahaan perlu memutuskan strategi yang paling tepat untuk mencegah bisnisnya mengalami krisis. Beberapa faktor mempengaruhi kinerja perusahaan; Struktur permodalan menjadi salah satunya; Struktur modal juga memegang peranan penting dalam meningkatkan kinerja perusahaan dengan mengambil keputusan yang tepat (Khan, 2012). Kinerja perusahaan dapat menunjukkan kepada kita kemampuan perusahaan untuk mendapatkan keuntungan dari aset, ekuitas, dan hutang. Ini juga merepresentasikan prestasi kerja perusahaan (Fachrudin, 2011). 
(Sofyaningsih \& Hardiningsih, 2011) menyatakan kinerja perusahaan yang baik dapat memperoleh keuntungan dari kegiatan operasinya, dimana hal tersebut menjadi fokus utama yang harus dicapai. Oleh karena itu keputusan yang tepat terkait pembiayaan dan investasi harus diputuskan oleh perusahaan untuk meningkatkan kinerja perusahaan dan kesejahteraan pemegang saham. Sedangkan menurut (Nugraha, 2013) keputusan struktur modal yang efektif dapat menurunkan biaya struktur modal perusahaan. Jika tidak, struktur modal yang buruk akan mempengaruhi jumlah struktur modal perusahaan. Besarnya kerugian struktur modal akan berdampak pada kinerja suatu perusahaan. Manajemen menggunakan penilaian kinerja perusahaan untuk menentukan kebijakan mana yang harus diambil di masa depan.

Perusahaan perlu berhati-hati dalam mengambil keputusan, termasuk keputusan Struktur Modal. Hal tersebut mengacu pada bagaimana perusahaan dapat mendukung kegiatan usahanya untuk dapat bertahan di industri yang membutuhkan sejumlah modal yang digunakan untuk membiayai operasional perusahaan sehari-hari, baik untuk investasi maupun untuk keperluan lainnya. Struktur Modal dapat diartikan sebagai suatu komposisi dana yang mendanai suatu perusahaan atau firma yang terdiri dari modal jangka panjang dan kewajiban jangka pendek (Nirajini \& Priya, 2013). Secara umum struktur permodalan terdiri dari hutang, saham biasa dan preferen. Hutang dapat diartikan dengan pinjaman dan wesel bayar, surat hutang, obligasi, dan lainnya (Chadha \& Sharma, 2015).

Struktur modal menjadi vital karena setiap kesalahan dalam proses pengambilan keputusan dapat menyebabkan perusahaan mengalami krisis atau bahkan kebangkrutan. Oleh karena itu, manajer dituntut untuk membuat strategi dalam mengelola struktur modal. Strategi harus dibuat untuk meningkatkan nilai perusahaan dan mengurangi biaya modal dan risiko. Selain itu, perusahaan berusaha mengoptimalkan struktur permodalan untuk meminimalisir biaya modal sehingga nilai perusahaan dapat meningkat dari sudut pandang keuangan. Tujuan perusahaan adalah menciptakan nilai. Struktur modal yang optimal merupakan campuran ekuitas dan hutang, dimana manfaat hutang lebih tinggi daripada biaya hutang (Mand \& Singh, 2015). Manajer keuangan dan bahkan peneliti telah mencoba menemukan cara untuk mengoptimalkan struktur modal, tetapi masih belum ada metode yang tepat untuk mengontrol tingkat struktur modal yang optimal (San \& Heng, 2011).

Dalam penelitian ini, peneliti ingin mengetahui pengaruh antara struktur modal dan kinerja perusahaan yang diukur dengan profitabilitas perusahaan. Penelitian ini merupakan perusahaan food and beverage di Indonesia yang terdaftar di Bursa Efek Indonesia dari tahun 2013 sampai dengan tahun 2019. Peneliti akan menggunakan beberapa variabel independen yang terdiri dari hutang jangka pendek dan hutang jangka panjang sebagai proksi dari struktur modal, arus kas. dari aktivitas operasi, pertumbuhan penjualan, dan ukuran perusahaan sebagai variabel kontrol. Sebaliknya return on asset akan merepresentasikan kinerja perusahaan sebagai variabel dependen dalam penelitian ini. Berdasarkan latar belakang yang telah dijelaskan sebelumnya, maka peneliti ingin 
mengetahui melalui penelitian yang berjudul "Pengaruh Struktur Modal Terhadap Kinerja Perusahaan pada Perusahaan Makanan dan Minuman di Indonesia".

Berdasarkan permasalahan yang telah dijelaskan di atas, maka dibuatlah penelitian untuk menganalisis perusahaan food and beverage dengan menganalisis pengaruh struktur modal terhadap kinerja perusahaan. Variabel independen penelitian ini terdiri dari struktur modal yang diwakili oleh hutang jangka pendek, hutang jangka panjang, arus kas dari aktivitas operasi, pertumbuhan penjualan, dan ukuran perusahaan. Oleh karena itu, kinerja perusahaan dinyatakan dalam profitabilitas, dan pengembalian aset adalah variabel dependen. Selain itu juga menganalisis pengaruh variabel independen tersebut terhadap variabel dependen pada perusahaan makanan dan minuman.

Berdasarkan latar belakang di atas maka tujuan dari penelitian adalah untuk mengetahui apakah terdapat pengaruh parsial yang signifikan dari:

1. Hutang Jangka Pendek terhadap Pengembalian Aset perusahaan makanan dan minuman di Indonesia.

2. Hutang Jangka Panjang terhadap Pengembalian Aset perusahaan makanan dan minuman di Indonesia.

3. Arus Kas dari Aktivitas Operasi terhadap Pengembalian Aset perusahaan makanan dan minuman di Indonesia.

4. Pertumbuhan Penjualan terhadap Return on Assets industri manufaktur makanan dan minuman di Indonesia.

5. Ukuran Perusahaan terhadap Pengembalian Aset perusahaan makanan dan minuman di Indonesia.

6. Terdapat pengaruh simultan yang signifikan antara Hutang Jangka Pendek, Hutang Jangka Panjang, Arus Kas dari Aktivitas Operasi, Pertumbuhan Penjualan, dan Ukuran Perusahaan terhadap Return On Assets pada perusahaan Makanan dan Minuman di Indonesia.

7. Untuk mengetahui variabel independen mana yang memiliki pengaruh paling signifikan terhadap Return On Assets pada perusahaan Food and Beverage di Indonesia

Dengan mengetahui faktor-faktor yang mempengaruhi profitabilitas perusahaan maka manajemen dapat fokus kepada faktor-faktor ini. Perusahaan dihadapkan dunia persaingan yang kompetitif dan dinamis. Di sisi lain manajemen memiliki sumber daya yang terbatas. Apabila manajemen dapat fokus pada hal-hal yang paling mempengaruhi profitabilitas maka harapannya profitabilitas perusahaan akan meningkat. Sementara itu investor dapat menggunakan temuan dari penelitian ini untuk melakukan penilaian terhadap perusahaan untuk selanjutnya berinvestasi di perusahaan yang paling memiliki prospek di masa depan. 


\section{Metode Penelitian}

Peneliti menggunakan beberapa metode untuk memudahkan mereka dalam memproses pengumpulan data, menganalisis dan memahaminya. Ada Metode Kuantitatif, Metode Kualitatif dan Metode Campuran. Metode kuantitatif dapat diartikan sebagai metode yang dikumpulkan melalui data sekunder yang diukur dengan angka dan dapat diukur dalam bentuk data statistik. Sedangkan metode kualitatif dapat diartikan sebagai metode yang dikumpulkan melalui data primer berupa wawancara, kuisioner dan observasi yang akan diinterpretasikan oleh peneliti di bagian akhir. Kemudian metode campuran dihasilkan dari kombinasi metode kuantitatif dan kualitatif.

Metode kuantitatif menerapkan mekanisme deduktif dengan membangun hipotesis teoritis untuk memperjelas pengaruh variabel analisis. Semua teori ditempatkan dalam penelitian, yang akan mengarahkan peneliti untuk mendukung atau membantah teori tersebut secara analitik, karena hasil akhir dari analisis kuantitatif akan diwakili oleh angka dan data statistik.

Berdasarkan perhitungan dan angka yang diambil melalui laporan keuangan tahunan perusahaan makanan dan minuman di Indonesia, untuk mendukung peneliti dalam mengolah dan menganalisis datanya maka digunakan metode kuantitatif dalam penelitian ini karena skala variabel penelitian ini. atau pengukuran sebagian besar merupakan rasio dan interval, yang berarti jumlah kalkulasi akan dibutuhkan. Penelitian ini akan mendapatkan keluaran yang obyektif karena banyaknya perhitungan dan statistik data.

Langkah pertama yang dilakukan adalah mengidentifikasi masalah atau fenomena yang ingin diketahui peneliti. Dilanjutkan dengan mengembangkan pertanyaan penelitian segera setelah menemukan masalah penelitian ini. Untuk membuat hipotesis, mengumpulkan dan menemukan tinjauan pustaka merupakan langkah penting yang harus dilakukan oleh peneliti. Dengan membaca jurnal, buku, dan semua sumber topik terkait, peneliti akan mengetahui banyak variabel yang dipilih sebagai variabel dependen dan independen dalam penelitian ini; semua sumber itu disebut tinjauan pustaka.

Setelah menentukan variabel dependen dan variabel independen yang akan digunakan, peneliti akan membuat kerangka teori. Kerangka teori dapat diartikan sebagai landasan fundamental penelitian, yang merupakan model konseptual yang menunjukkan hubungan antara variabel dependen dan variabel independen

Setelah membuat kerangka teori, peneliti menentukan metode mana yang akan digunakan untuk penelitian. Peneliti kemudian mulai mengumpulkan data yang diperlukan untuk menganalisis penelitian, seperti data laporan tahunan perusahaan dari situs resmi perusahaan dan BEI. Semua data yang terkumpul akan dimasukkan ke dalam Microsoft Excel 2016, dan semua data mentah tersebut akan diolah menggunakan Eviews Versi 10 yang akan memberikan hasilnya. Hasil atau keluaran akhir akan dianalisis dan diinterpretasikan dengan penelitian atau literatur sebelumnya yang telah dikumpulkan sebelumnya. Kesimpulan diambil setelah langkah-langkah di atas, dan 
kesimpulan tersebut akan menjawab semua pertanyaan masalah penelitian diikuti dengan rekomendasi kepada beberapa pihak terkait tertentu.

\section{Hasil dan Pembahasan}

\section{A. Analisa Deskriptif}

\section{Tabel 1}

Descriptive Statistics

\begin{tabular}{cccccccc} 
& Y_ROA & X1_STD & X2_LTD & X3_CFO & X4_GROWTH X \\
\hline Mean & 0,06 & 0,30 & 0,17 & $303.292,50$ & 0,14 & 14,41 \\
Median & 0,06 & 0,30 & 0,15 & $147.807,00$ & 0,12 & 14,21 \\
Maximum & 0,18 & 0,56 & 0,47 & $3.303 .864,00$ & 1,25 & 16,76 \\
Minimum & $(0,07)$ & 0,11 & 0,02 & $862.340,00$ & 0,32 & 12,62 \\
Std Deviasi & 0,06 & 0,13 & 0,13 & $578.171,50$ & 0,24 & 1,00 \\
Observasi & 63 & 63 & 63 & 63 & 63 & 63
\end{tabular}

Pada Tabel 1 terdiri dari 6 variabel yang digunakan dalam penelitian ini. Yang dapat dibagi menjadi variabel dependen dan variabel independen; ROA mewakili variabel dependen, dan STD, LTD, CFO, GROWTH dan SIZE mewakili variabel independen. Penelitian ini terdiri dari 63 data observasi dari 9 perusahaan berbeda dari industri yang dipilih, pengambilan data dimulai dari tahun 2013-2019.

Return on Asset (ROA) merupakan variabel dependen dalam penelitian ini. Rerata ROA adalah 0,060476, dan standar deviasi 0,062321 menunjukkan bahwa data sering terdistribusi sekitar $0,060476 \pm 0,062321$. Standar deviasi yang lebih besar dari nilai rata-rata menunjukkan bahwa return on asset data sampel observasi sangat fluktuatif. Nilai ROA minimum sebesar -0,07 terjadi pada PT Prahsida Aneka Niaga Tbk pada tahun 2015 dan 2018; ini menunjukkan bahwa perusahaan tidak dapat menghasilkan keuntungan melalui asetnya. Nilai maksimum 0,18 terjadi pada PT Wilmar Cahaya Indonesia Tbk tahun 2016; ini menunjukkan kemampuan yang kuat untuk menghasilkan keuntungan melalui asetnya.

Utang Jangka Pendek (PMS) merupakan variabel independen dalam penelitian ini. Nilai rata-rata STD sebesar 0,297778, dan standar deviasi 0,125331, hal ini menunjukkan bahwa data sering tersebar sekitar 0,297778 \pm 0,125331. Standar deviasi yang lebih kecil dari nilai mean menunjukkan bahwa hutang jangka pendek fluktuasi data sampel observasi relatif kecil. Nilai minimum STD sebesar 0,11 terjadi pada PT Nippon Indosari Corpindo Tbk pada tahun 2016. Sedangkan nilai maksimum STD sebesar 0,56 terjadi pada PT Wilmar Cahaya Indonesia Tbk pada tahun 2014.

Long-term debt (LTD) merupakan variabel independen dalam penelitian ini. Nilai rata-rata LTD adalah 0.170794, dan standar deviasi 0.127991, hal ini menunjukkan bahwa data sering didistribusikan sekitar $0.170794 \pm 0.127991$. Standar deviasi yang lebih kecil dari nilai rata-rata menunjukkan bahwa hutang jangka panjang fluktuasi data sampel observasi relatif kecil. Nilai minimum LTD sebesar 0,02 terjadi pada PT Ultra 
Jaya Milk Industry \& Trading Company Tbk pada tahun 2019. Sedangkan nilai maksimum sebesar 0,47 terjadi pada PT Tri Banyan Tirta Tbk pada tahun 2019.

Arus kas dari aktivitas operasi (CFO) merupakan variabel independen dalam penelitian ini. Nilai rata-rata CFO adalah 303292,5, dan standar deviasi 578171,5, hal ini menunjukkan bahwa data sering terdistribusi sekitar 303292,5 $\pm 578171,5$. Standar deviasi yang lebih besar dari nilai mean menunjukkan bahwa data arus kas dari sampel pengamatan kegiatan operasi mengalami fluktuasi fluktuasi selama periode pengamatan. Nilai CFO minimum sebesar -862340 terjadi pada PT Mayora Indah Tbk pada tahun 2014. Sedangkan nilai maksimum sebesar 3303864 terjadi pada PT Mayora Indah Tbk pada tahun 2019.

Pertumbuhan penjualan (GROWTH) merupakan variabel independen dalam penelitian ini. Nilai rata-rata GROWTH 0.139524, dan standar deviasi 0.241423 , hal ini menunjukkan bahwa data sering terdistribusi sekitar $0.139524 \pm 0.241423$. Standar deviasi yang lebih besar dari nilai rata-rata menunjukkan bahwa data pertumbuhan penjualan sangat berfluktuasi selama periode pengamatan. Nilai GROWTH minimum sebesar -0,32 yang terjadi pada PT Tri Banyan Tirta Tbk pada tahun 2014 menunjukkan bahwa perusahaan gagal meningkatkan penjualannya dari tahun ke tahun. Sedangkan nilai maksimal sebesar 1,25 terjadi pada PT Wilmar Cahaya Indonesia Tbk pada tahun 2013 menunjukkan bahwa perusahaan berhasil meningkatkan penjualannya dari tahun ke tahun.

Ukuran perusahaan (SIZE) merupakan variabel independen dalam penelitian ini. Nilai mean SIZE 14,40698, dan standar deviasi 1,004292, hal ini menunjukkan bahwa data sering didistribusikan sekitar 14,40698 \pm 1,004292. Standar deviasi yang lebih kecil dari nilai rata-rata menunjukkan bahwa ukuran perusahaan dari fluktuasi data sampel observasi relatif kecil. Nilai SIZE minimum 12,62 terjadi pada PT Sekar Laut Tbk pada tahun 2013. Sedangkan nilai maksimum sebesar 16,76 pada PT Mayora Indah Tbk pada tahun 2019 .

\section{B. Analisis Data}

1. Analisis Linear Regresi Berganda

Analisis regresi berganda memberikan metode untuk mengevaluasi hubungan antara variabel dependen dan variabel independen secara objektif. Koefisien regresi membuktikan kepentingan relatif masing-masing variabel independen dalam memprediksi variabel dependen (Sekaran \& Bougie, 2019). Model random effect dalam penelitian ini melakukan analisis regresi berganda. Tabel 2 menunjukkan hasil analisis regresi berganda: 


\section{Table 2}

Multiple Regression Analysis Result

\begin{tabular}{lrrrr} 
Variable & Coefficient & Std. Error & \multicolumn{1}{c}{ t-Statistic } & Probabilities \\
\hline C & $-0,03$ & 0,05 & $(0,76)$ & 0,45 \\
X1_STD & $-0,23$ & 0,04 & $(5.526 .686,00)$ & 0,00 \\
X2_LTD & $-0,19$ & 0,04 & $(4.993 .083,00)$ & 0,00 \\
X3_CFO & 0,00 & 0,00 & $3.262 .084,00$ & 0,00 \\
X4_GRO & 0,09 & 0,02 & $5.762 .947,00$ & 0,00 \\
X5_SIZE & 0,01 & 0,00 & $4.574 .001,00$ & 0,00
\end{tabular}

Source: Proceed data by Eviews 10

Persamaan regresi berganda harus didasarkan pada koefisien regresi masingmasing variabel independen. Berdasarkan tabel 4.16, persamaan regresi berganda dapat dirumuskan sebagai berikut:

$$
\begin{gathered}
Y=-0.034960-0.228280 X_{1}-0.193838 X_{2}+0.000000 X_{3}+0.094076 X_{4} \\
+0.012216 X_{5}
\end{gathered}
$$

\section{Interpretasi Hasil}

1. Pengaruh Utang Jangka Pendek terhadap Return On Asset

Hipotesis pertama menyatakan bahwa hutang jangka pendek berpengaruh signifikan terhadap pengembalian aset perusahaan makanan dan minuman di Indonesia. Tabel 4.17 menunjukkan nilai signifikansi kinerja perusahaan sebesar 0,0000, artinya diterima. Hutang jangka pendek memiliki pengaruh negatif yang signifikan terhadap pengembalian aset; Hal tersebut dibuktikan dengan koefisien regresi sebesar $-0,228280$. Hal tersebut menunjukkan bahwa terdapat pengaruh negatif antara hutang jangka pendek terhadap return on asset.

Hal tersebut menunjukkan bahwa peningkatan hutang jangka pendek mempengaruhi penurunan nilai pengembalian aset. Artinya, temuan penelitian menemukan bahwa perusahaan yang terdaftar dalam sampel merasa kesulitan untuk membayar kembali hutang jangka pendek mereka dengan total aset perusahaan. Dengan demikian, semakin banyak perusahaan memiliki hutang jangka pendek maka profitabilitas perusahaan akan semakin kecil. Hasil penelitian ini sejalan dengan temuan penelitian sebelumnya oleh (Vătavu, 2015) yang menemukan bahwa hutang jangka pendek berpengaruh negatif terhadap profitabilitas dan (Kamal, 2018) menemukan bahwa hutang jangka pendek memiliki pengaruh negatif yang signifikan terhadap return on asset. Sedangkan (Maria, Wiagustini, \& Sedana, 2019) dan (Al-Taani, 2013) menemukan bahwa hutang jangka pendek memiliki pengaruh yang tidak signifikan terhadap return aset.

2. Pengaruh Utang Jangka Panjang terhadap Return On Assets

Hipotesis kedua menyatakan bahwa hutang jangka panjang berpengaruh signifikan terhadap pengembalian aset perusahaan makanan dan minuman di 
Indonesia. Tabel 4.17 menunjukkan nilai signifikansi kinerja perusahaan sebesar 0,0000, artinya diterima. Hutang jangka panjang memiliki pengaruh negatif yang signifikan terhadap pengembalian aset; Hal tersebut dibuktikan dengan koefisien regresi sebesar -0.193838 . Hal tersebut menunjukkan bahwa terdapat pengaruh negatif antara hutang jangka panjang terhadap return on asset.

Hal tersebut menunjukkan bahwa peningkatan hutang jangka panjang berdampak pada penurunan nilai pengembalian aset. Artinya, temuan penelitian menemukan bahwa perusahaan yang terdaftar dalam sampel merasa kesulitan untuk membayar kembali hutang jangka panjang mereka dengan total aset perusahaan. Dengan demikian, semakin banyak perusahaan memiliki hutang jangka panjang, maka profitabilitas perusahaan akan semakin kecil. Hasil penelitian yang didukung oleh penelitian (Al-Taani, 2013) menemukan bahwa hutang jangka panjang memiliki pengaruh negatif yang signifikan terhadap return on asset. Namun kemudian penelitian (Maria et al., 2019), (Nirajini \& Priya, 2013), dan (Vătavu, 2015) menemukan hasil pengaruh yang signifikan positif juga temuan (Kamal, 2018) menemukan pengaruh negatif yang tidak signifikan.

3. Pengaruh Arus Kas dari Aktivitas Operasi terhadap Return On Assets

Hipotesis ketiga menyatakan bahwa arus kas dari aktivitas operasi berpengaruh signifikan terhadap return on asset perusahaan makanan dan minuman di Indonesia. Tabel 4.17 menunjukkan bahwa nilai signifikansi kinerja perusahaan sebesar 0,0019, artinya diterima. Arus kas dari aktivitas operasi memiliki pengaruh menguntungkan yang signifikan terhadap pengembalian aset; itu dibuktikan dengan koefisien regresi sebesar 0,000000. Hal tersebut menunjukkan adanya pengaruh positif antara arus kas dari aktivitas operasi terhadap return on asset.

Hal tersebut menunjukkan peningkatan arus kas dari aktivitas operasi berdampak pada peningkatan nilai pengembalian aset. Artinya, temuan penelitian menemukan bahwa perusahaan yang masuk dalam sampel dapat mengelola arus kas operasional melalui kegiatan usahanya untuk menghasilkan keuntungan. Nilai kas yang tinggi dari aktivitas operasional menunjukkan bahwa bisnis berfungsi dengan baik dan fleksibilitas keuangan telah dicapai dalam pengambilan keputusan, perencanaan strategis, dan manajemen perusahaan secara keseluruhan (Gillingham, Houde, \& Van Benthem, 2019). Penelitian ini bertentangan dengan penelitian (Sasongko \& Apriani, 2016) bahwa arus kas dari aktivitas operasi memiliki pengaruh negatif yang signifikan terhadap return on asset.

4. Pengaruh Pertumbuhan Penjualan terhadap Return On Assets

Hipotesis keempat menyatakan bahwa pertumbuhan penjualan berpengaruh signifikan terhadap return on asset perusahaan makanan dan minuman di Indonesia. Tabel 4.17 menunjukkan bahwa nilai signifikansi kinerja perusahaan adalah 0,0000, artinya diterima. Pertumbuhan penjualan memiliki pengaruh menguntungkan yang signifikan terhadap laba atas aset; Hal tersebut dibuktikan 
dengan koefisien regresi sebesar 0,094076. Hal tersebut menunjukkan bahwa terdapat pengaruh positif antara pertumbuhan penjualan terhadap return on asset.

Hal tersebut menunjukkan bahwa peningkatan pertumbuhan penjualan berdampak pada peningkatan nilai pengembalian aset. Salah satu sumber pendapatan perusahaan berasal dari penjualan, sehingga penjualan merupakan bagian yang vital dalam aktivitas perusahaan. Hasil penelitian menemukan bahwa perusahaan yang terdaftar dalam sampel penjualan mengalami peningkatan dan berpengaruh positif terhadap pendapatan perusahaan. Ini akan menguntungkan bagi perusahaan dengan jumlah penjualan yang tinggi karena akan meningkatkan arus kas dan profitabilitas perusahaan (Wikardi \& Wiyani, 2017). Hasil penelitian didukung oleh (Kamal, 2018) dan (Chadha \& Sharma, 2015) menemukan bahwa pertumbuhan penjualan memiliki pengaruh menguntungkan yang signifikan terhadap pengembalian aset. Namun hasil tersebut bertentangan dengan penelitian (Wikardi \& Wiyani, 2017) yang memberikan pengaruh yang tidak signifikan.

5. Pengaruh Ukuran Perusahaan terhadap Return On Assets

Hipotesis kelima menyatakan bahwa ukuran perusahaan berpengaruh signifikan terhadap return on asset perusahaan makanan dan minuman di Indonesia. Tabel 4.17 menunjukkan bahwa nilai signifikansi kinerja perusahaan adalah 0,0000, artinya diterima. Ukuran perusahaan memiliki pengaruh menguntungkan yang signifikan terhadap pengembalian aset; Hal tersebut dibuktikan dengan koefisien regresi sebesar 0,012216. Hal tersebut menunjukkan bahwa terdapat pengaruh positif antara ukuran perusahaan terhadap return on asset.

Hal tersebut menunjukkan bahwa peningkatan ukuran perusahaan berpengaruh terhadap peningkatan nilai return on asset. Artinya temuan penelitian menemukan bahwa ketika ukuran perusahaan yang tercantum dalam sampel semakin membesar, perusahaan tersebut dapat menghasilkan keuntungan dari kegiatan operasional dan penjualannya. Peningkatan total aset mereka juga dapat mengukur peningkatan ukuran perusahaan. Semakin banyak aset yang dimiliki perusahaan, semakin besar pendapatan yang dapat dihasilkan dengan menggunakan lebih banyak aset dan memiliki profitabilitas yang lebih tinggi (Chadha \& Sharma, 2015). Struktur Modal dan Kinerja Perusahaan: Bukti empiris dari India tahun 2015. Hasil penelitian ini sejalan dengan temuan penelitian sebelumnya oleh (Wikardi \& Wiyani, 2017), (Chadha \& Sharma, 2015), dan (Kamal, 2018) menemukan bahwa ukuran perusahaan memiliki pengaruh menguntungkan yang signifikan terhadap pengembalian aset. Sedangkan (AyoOyebiyi, Ladokun, \& Taiwo, 2019) memiliki hasil yang berbeda, dimana terdapat pengaruh yang kecil terhadap return on asset.

6. Pengaruh Simultan dari Hutang Jangka Pendek, Hutang Jangka Panjang, Arus Kas dari Aktivitas Operasi, Pertumbuhan Penjualan dan Ukuran Perusahaan terhadap Return on Asset 
Hipotesis keenam menyatakan pengaruh yang signifikan antara hutang jangka pendek, hutang jangka panjang, arus kas dari aktivitas operasi, pertumbuhan penjualan, dan ukuran perusahaan terhadap return on asset pada perusahaan makanan dan minuman di Indonesia. Nilai probabilitas f-statistik adalah 0,000000; artinya nilainya kurang dari 0,05. Ini menjelaskan bahwa variabel dependen secara simultan dipengaruhi oleh semua variabel independen. Karena itu, itu diterima. Hutang jangka pendek, hutang jangka panjang, arus kas dari aktivitas operasi, pertumbuhan penjualan, dan ukuran perusahaan secara simultan dapat menjelaskan 52,6695\% variabel dependen. Sisanya, $47.3305 \%$ ditentukan oleh faktor lain yang tidak diteliti dalam penelitian ini.

7. Faktor yang Berpengaruh Paling Signifikan terhadap Return On Asset pada Perusahaan Makanan dan Minuman di Indonesia

Model yang dibangun oleh penelitian ini menunjukkan model bersifat moderate. Model ini dapat menjelaskan sebagian besar hal yang mempengaruhi profitabilitas perusahaan. Dan dari model tersebut tidak semua variabel berpengaruh signifikan. Terdapat variabel yang memiliki pengaruh signifikan dan terdapat variabel yang tidak memiliki pengaruh signifikan. Dari antara variabel tersebut maka pertumbuhan penjualan yang memiliki nilai signifikansi paling tinggi. Dengan demikian variabel pertumbuhan penjualan adalah variabel utama yang mendorong pertumbuhan profitabilitas perusahaan.

\section{Kesimpulan}

Berdasarkan hasil penelitian ini maka dapat diambil beberapa kesimpulan. Pertama, utang jangka pendek memiliki pengaruh negatif yang signifikan terhadap pengembalian aset. Hal tersebut menunjukkan bahwa sampel penelitian yang telah dipilih ini merasa kesulitan untuk membayar kembali hutang jangka pendek mereka dengan total aset perusahaan. Oleh karena itu, semakin banyak perusahaan memiliki hutang jangka pendek, maka profitabilitas perusahaan akan semakin kecil. Kedua utang jangka panjang memiliki pengaruh negatif yang signifikan terhadap pengembalian aset. Hal ini menunjukkan bahwa sampel penelitian yang telah dipilih ini merasa kesulitan untuk membayar kembali hutang jangka panjang mereka dengan total aset perusahaan. Oleh karena itu, semakin banyak perusahaan memiliki hutang jangka panjang, maka profitabilitas perusahaan akan semakin kecil. Ketiga, arus kas dari aktivitas operasi memiliki pengaruh menguntungkan yang signifikan terhadap pengembalian aset. Hal ini menunjukkan bahwa sampel penelitian yang dipilih mampu mengelola arus kas operasional melalui kegiatan usahanya untuk menghasilkan keuntungan.Keempat, pertumbuhan penjualan memiliki pengaruh menguntungkan yang signifikan terhadap pengembalian aset. Hal ini menunjukkan bahwa sampel penelitian yang dipilih jumlah penjualannya meningkat dan berpengaruh positif terhadap pendapatan perusahaan. Dengan jumlah penjualan yang tinggi akan meningkatkan profitabilitas perusahaan. Kelima, Ukuran perusahaan memiliki pengaruh menguntungkan yang signifikan terhadap pengembalian aset. Hal tersebut menunjukkan bahwa sampel dari penelitian ini 
Pengaruh Struktur Modal Terhadap Kinerja Perusahaan Perusahaan Makanan dan Minuman Di Indonesia

menemukan bahwa ketika ukuran perusahaan semakin besar, perusahaan tersebut dapat menghasilkan keuntungan dari kegiatan operasional dan penjualannya. 


\section{BIBLIOGRAFI}

Al-Taani, Khalaf. (2013). The relationship between capital structure and firm performance: evidence from Jordan. Journal of Finance and Accounting, 1(3), 4145.Google Scholar

Ayo-Oyebiyi, G. T., Ladokun, I. O., \& Taiwo, D. Jooda. (2019). Customer relationship management dimensions and Nigerian banks' performance: Evidence from Zenith Bank Plc. South Asian Journal of Social Studies and Economics, 1-8. Google Scholar

Chadha, Saurabh, \& Sharma, Anil K. (2015). Capital structure and firm performance: Empirical evidence from India. Vision, 19(4), 295-302. Google Scholar

Creswell, John W., \& Creswell, J. David. (2017). Research design: Qualitative, quantitative, and mixed methods approaches. Sage publications. Google Scholar

Fachrudin, Khaira Amalia. (2011). Analisis pengaruh struktur modal, ukuran perusahaan, dan agency cost terhadap kinerja perusahaan. Jurnal Akuntansi Dan Keuangan, 13(1), 37-46. Google Scholar

Gillingham, Kenneth, Houde, Sébastien, \& Van Benthem, Arthur. (2019). Consumer myopia in vehicle purchases: evidence from a natural experiment. National Bureau of Economic Research. Google Scholar

Kamal, M. Basri. (2018). Pengaruh Receivable Turn Over Dan Debt To Asset Ratio (DAR) Terhadap Return On Asset (ROA) Pada Perusahaan Pertanian Yang Terdaftar Di Bursa Efek Indonesia (BEI). Jurnal Ilmiah Manajemen Dan Bisnis, 17(2). Google Scholar

Khan, Abdul Ghafoor. (2012). The relationship of capital structure decisions with firm performance: A study of the engineering sector of Pakistan. International Journal of Accounting and Financial Reporting, 2(1), 245. Google Scholar

Mand, Harvinder Singh, \& Singh, Manjit. (2015). Capital Structure and Earnings per Share: An Empirical Analysis of Indian Corporate Sector. International Journal of Financial Management, 5(3). Google Scholar

Maria, Madalena, Wiagustini, L. P., \& Sedana, I. (2019). Pengaruh Ukuran Perusahaan, Leverage Dan Liquiditas Terhadap Profitabilitas Di Perusahaan Esperanca TimorOan (ETO) Dili Timor-Leste. E-Jurnal Ekonomi Dan Bisnis Universitas Udayana, 8(1), 23-40. Google Scholar

Neuman, W. Lawrence. (2014). Social research methods: Qualitative and quantitative approaches: Pearson new international edition. Pearson Education Limited. Google Scholar

Nirajini, A., \& Priya, K. B. (2013). Impact of capital structure on financial performance 
of the listed trading companies in Sri Lanka. International Journal of Scientific and Research Publications, 3(5), 1-9. Google Scholar

Nugraha, Arif Ardhi. (2013). Analisis pengaruh struktur modal terhadap kinerja perusahaan yang tergabung dalam Indeks Kompas 100. Management Analysis Journal, 2(1). Google Scholar

Peterson, Hayley. (2017). The retail apocalypse has officially descended on America. Business Insider, 21. Google Scholar

Purwanto, Purwanto. (2011). Strategi Bersaing untuk Mengoptimalkan Kapasitas Produksi: Studi Kasus pada PT. Jaya Indah Casting, Bekasi. The Winners, 12(2), 154-179. Google Scholar

San, Ong Tze, \& Heng, Teh Boon. (2011). Capital structure and corporate performance of Malaysian construction sector. International Journal of Humanities and Social Science, 1(2), 28-36. Google Scholar

Saputra, Beny Dwi, \& Sukirno, Sukirno. (2020). Kesiapan Kerja Siswa Program Akuntansi Pada Sekolah Menengah Kejuruan. Jurnal Kependidikan: Penelitian Inovasi Pembelajaran, 4(1), 139-151. Google Scholar

Sasongko, Hendro, \& Apriani, Dewi. (2016). Analisis Pengaruh Arus Kas Terhadap Profitabilitas Pada PT Mayora Indah Tbk. Jurnal Ilmiah Akuntansi, 2(1), 1-15. Google Scholar

Sekaran, Uma, \& Bougie, Roger. (2019). Research methods for business: A skill building approach. john wiley \& sons. Google Scholar

Sofyaningsih, Sri, \& Hardiningsih, Pancawati. (2011). Struktur kepemilikan, kebijakan dividen, kebijakan utang dan nilai perusahaan. Dinamika Keuangan Dan Perbankan, 3(1), 68-87. Google Scholar

Vătavu, Sorana. (2015). The impact of capital structure on financial performance in Romanian listed companies. Procedia Economics and Finance, 32, 1314-1322. Google Scholar

Wikardi, Lucya Dewi, \& Wiyani, Natalia Titik. (2017). Pengaruh Debt to Equity Ratio, Firm Size, Inventory Turnover, Assets Turnover dan Pertumbuhan Penjualan Terhadap Profitabilitas (Studi Kasus Pada Industri Makanan dan Minuman yang Terdaftar di BEI Periode 2011-2015). Jurnal Online Insan Akuntan, 2(1), 99-118. Google Scholar

Copyright holder:

Pandu Adi Cakranegara, Debby Danila Wati (2021)

First publication right:

Syntax Literate: Jurnal Ilmiah Indonesia 
Pandu Adi Cakranegara, Debby Danila Wati

This article is licensed under:

(c) $\underset{\mathrm{EY}}{(\text { ) }}$ (2) 